\title{
The interaction model of business and state as a factor in human
}

\author{
resource management \\ Tatiana V. Skryl ${ }^{\mathrm{a}^{*}}$, Vladimir S. Osipov ${ }^{b}$, Vadim O. Evseev $^{a}$ \\ ${ }^{a}$ Plekhanov Russian University of Economics, Russia \\ ${ }^{\mathrm{b}}$ Market Economy Institute of Russian Academy of Sciences, \\ Lomonosov Moscow State University, Russia \\ *Corresponding author: Tatiana V. Skryl, PhD, t_skryl@mail.ru
}

\begin{abstract}
The paper presents the economic model representing the inter-relationship between the state and business with respect to human resource management. The model connects the categories such as labor, money, working time, life being and productivity of the working person. In the process of implementing this model, the authors carried out the experiments that showed modern hidden mechanisms of exploitation of labor, the level of economic freedom of the worker from state officials. The paper demonstrates how a whole country could lose labor potential due to the imperfections of public administration.
\end{abstract}

Key words: human resource; management; corruption; national debt; pensions; economic model; state

\section{Introduction}

The state role and its degree of participation in the raising the standard of living of the population, as well as in management and regulation of socio-economic processes, is the subject of constant public and scientific discussions. On the other hand, the private capital and corrupt state officials, using their administrative and political capabilities, committed to building a personal financial capital and produce economic rents that provides them, their children and grandchildren an elitist standard of living.

At present, we see the failure of the role and idea of the state in a market economy. The indicators of social stratification of society and the growth of super-rich people became unacceptably high in many countries and led to the need for a systematic and social analysis of socio-economic mechanisms. Capitalism cannot exist without exploitation, both of the 
working people of the country, and of exploitation and even deformation of the mechanisms of its state system (Osipov V., Skryl T.) ${ }^{1}$. Striving for the economic independence from the state, the private business and some part of state administrators begin to create a legislative base and program documents that promote both exploitation and impoverishment of the people. Actually, they implement corruption schemes with the subsequent withdrawal of financial resources outside the country and the subsequent creation of the mechanism of financial and economic rent.

\section{Experimental}

The modern science suggests using the methodology of system analysis, which makes it possible to identify the sources and generators of social and economic deformations.

The authors developed and presented an economic model that economically links the categories of labor, money, working time and the lifespan of a single working person. On a base of the model, corresponding experiments were conducted, which showed the modern mechanisms of exploitation of the labor force by the state.

Let us consider a hypothetical model of the "worker-state" interaction that would correspond to the principles of a social state, and that would correspond to social relations worthy of the 21st century.

Model parameters:

1. The state, as a smart and strategic employer, provides its citizens with modern workplaces.

2. The state provides (opens) to its citizen a long-term credit line for meeting its basic needs from 1 year to 19 years.

3. For forty years of the labor activity, a citizen, at a given workplace, must do the following: earn a pension, support and meet his current needs through his salary, return state-funded financial means that were spent on him for nineteen years (nursery, primary, secondary and higher education, medical care, etc.).

4. A citizen undertakes to preserve his health, to receive the necessary education, to return the credit received for his development, from 20 to 60 years to work in the sphere of production or services in order to produce GDP, from 60 years to get a well-deserved pension.

Let us consider how the model looks in figures on its main blocks (Table 1).

Block 1. Initial data. The initial data for the model are taken from Federal State Statistics Service of Russian Federation: 1) labor productivity; 2) average salary; 3) level of 
Table 1 - The balance of the revenue and expenditure of the working person

\begin{tabular}{|c|c|c|c|}
\hline & & Time & Money \\
\hline & & $\begin{array}{l}\text { Time } \\
\text { expenses, } \\
\text { years }\end{array}$ & $\begin{array}{l}\text { For the } \\
\text { specified time, } \\
\text { rubles }\end{array}$ \\
\hline Labor & Revenue - "Production" & & \\
\hline 1 & $\begin{array}{l}\text { 1.1. Duration of employment } \\
\text { from } 20 \text { to } 60 \text { years old } \\
\text { 1.2. GDP Per capita is } 551395 \text { rubles per year, corruption } \\
\text { level is } 15 \% \text { of GDP }\end{array}$ & 40 & 22055800 \\
\hline Life being & Expenditure - “Consumption” & & \\
\hline 2. & $\begin{array}{l}\text { 2.1. The cost of basic needs } \\
\text { from } 1 \text { to } 19 \text { years old } \\
\text { The average cost per year is } 180000 \text { rubles per year }\end{array}$ & 19 & 3420000 \\
\hline 3. & $\begin{array}{l}\text { 3.1. The cost of basic needs } \\
\text { from } 20 \text { to } 60 \text { years old } \\
\text { The average cost per year is } 360000 \text { rubles per year }\end{array}$ & 40 & 14400000 \\
\hline 4 & $\begin{array}{l}\text { 4.1. The cost of basic needs } \\
\text { from } 61 \text { to } 80 \text { years old } \\
\text { The average cost per year is } 216000 \text { rubles per year }\end{array}$ & 20 & 4104000 \\
\hline 5. & Total cost of basic needs & 80 & 21924000 \\
\hline 6. & Balance: "Production - Consumption" & & 131800 \\
\hline
\end{tabular}

Source: Authors' calculations based on data from Federal State Statistics Service of Russian Federation (2015) ${ }^{2}$

consumption for young people, from 1 to 19 years; 4) level of consumption of pensioners, from 60 years to the given time of survival.

Block 2. Correction coefficients. There are corrective factors in the model: 1) to labor productivity; 2) to the salary; 3) to the levels of consumption of youth and pensioners; 4) by the time of survival; 5) to the level of corruption; 6) to the total working time (increase of work experience).

Block 3. Calculated values. The calculated values of the model are: 1) the cost of living of one person from 1 year to his death; 2) the total value of GDP produced by one person from the age of 20 to 60 , or with another period of retirement; 3) "revenue and expenditure" component of the human life; 4) total working time; 5) impact of a given level of corruption on the distribution of working time on oneself and on the state; 6) effect of corrective coefficients on the calculated values.

Block 4. Evaluation of economic deformations. This block calculates the loss of working time in years on the existing deformations in public relations: losses due to the withdrawal of capital, loss due to an unacceptably high Gini coefficient, etc. 
Block 5. Valid values. The model does not consider the following dependencies: 1) loss of the working time due to a decrease in the standard of living (UN indicator - the specific weight of unhealthy life from the total life expectancy); 2) decrease in annual GDP due to loss of the working time; 3) influence of inflation.

As can be seen from Table 1, one average working citizen during 40 years completely provided his basic needs. It means that for 40 years he worked only for himself: he returned the loan, which he had previously received for his development (from 1 to 19 years old), provided his needs in the age of 20 to 60 years old, provided himself a pension for 61 to 80 years old.

\section{Results and Discussions}

The state has several options for getting out of the situation: 1) increase the labor productivity; 2) reduce the level of corruption; 3) reduce the standard of living of the population; 4) reduce the life expectancy; 5) increase a period of work experience; 6) get into debt.

Fig. 1 shows the non-linear dependence of the increase in time required for the development of the state with a decreasing level of corruption of up to $1 \%$. We can see that with a corruption level of $15 \%$ of GDP, we can deduct about 6 years from a work-time fund of 40 years when worker works to meet the needs of the unscrupulous officer during. Fig. 1 also shows that a noticeable effect from the fight against corruption can be obtained by reducing it to $8 \%$. It seems that the fight against corruption must take a lot of time and cost a lot of money, so the government's preferred option is shown in Fig. 2.

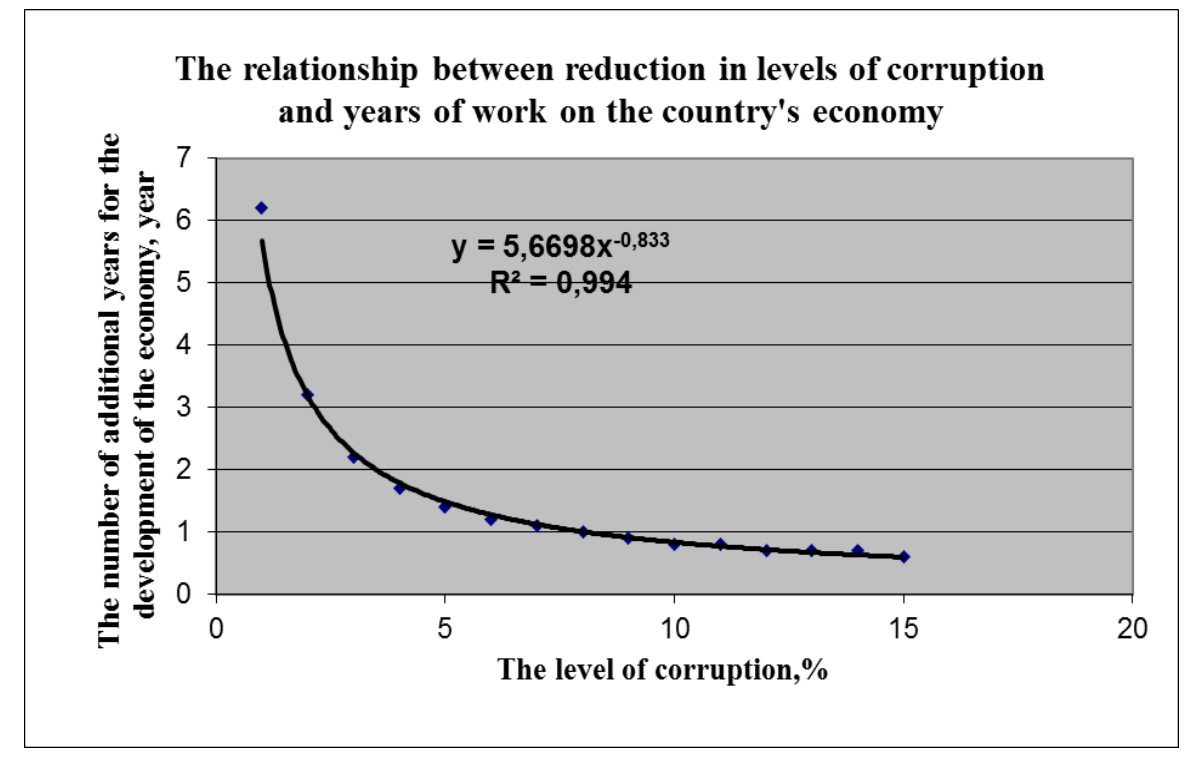

Fig. 1. - Extra time of work life, involved in the development of the economy (related to corruption level) . 


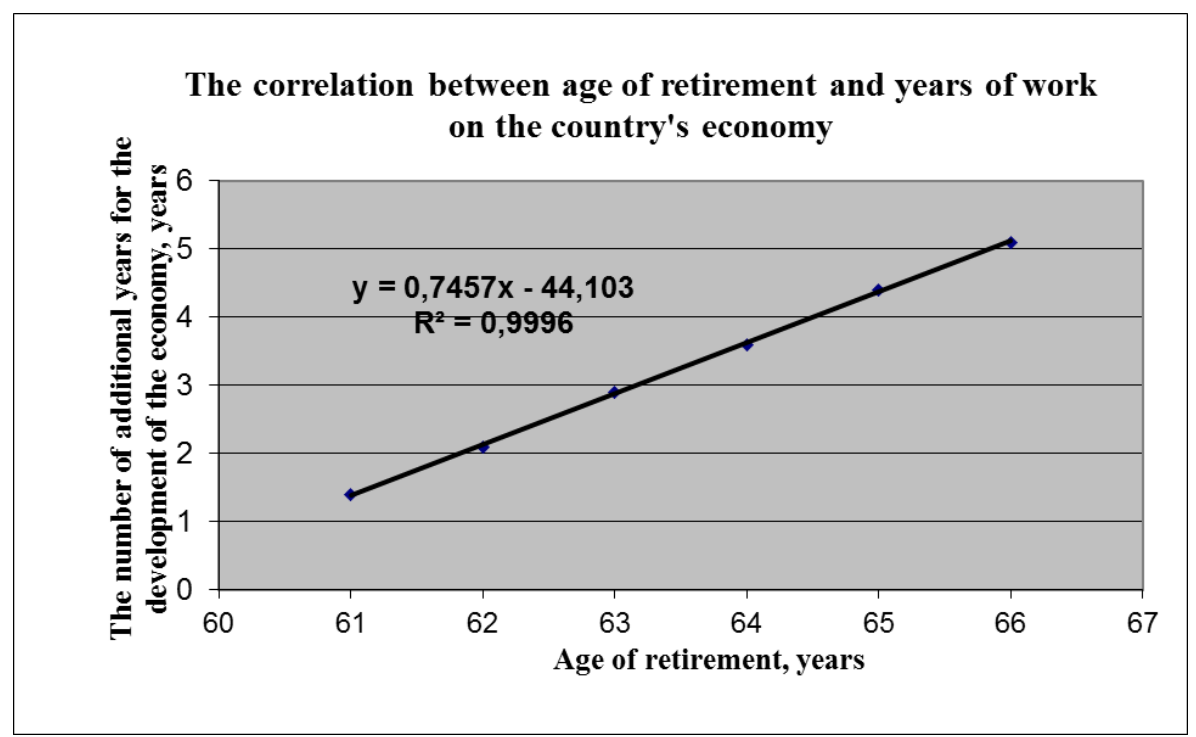

Fig. 2. - Extra time of work life, involved in the development of the economy (related to the age of retirement).

The option in Fig.2 refers to extensive methods of increasing the efficiency of the economy. The extensive way of development is ineffective not only at the stage of production, but also in management.

Fig. 3 shows the dependence of the increase in years on the development of the economy with a planned increase in labor productivity

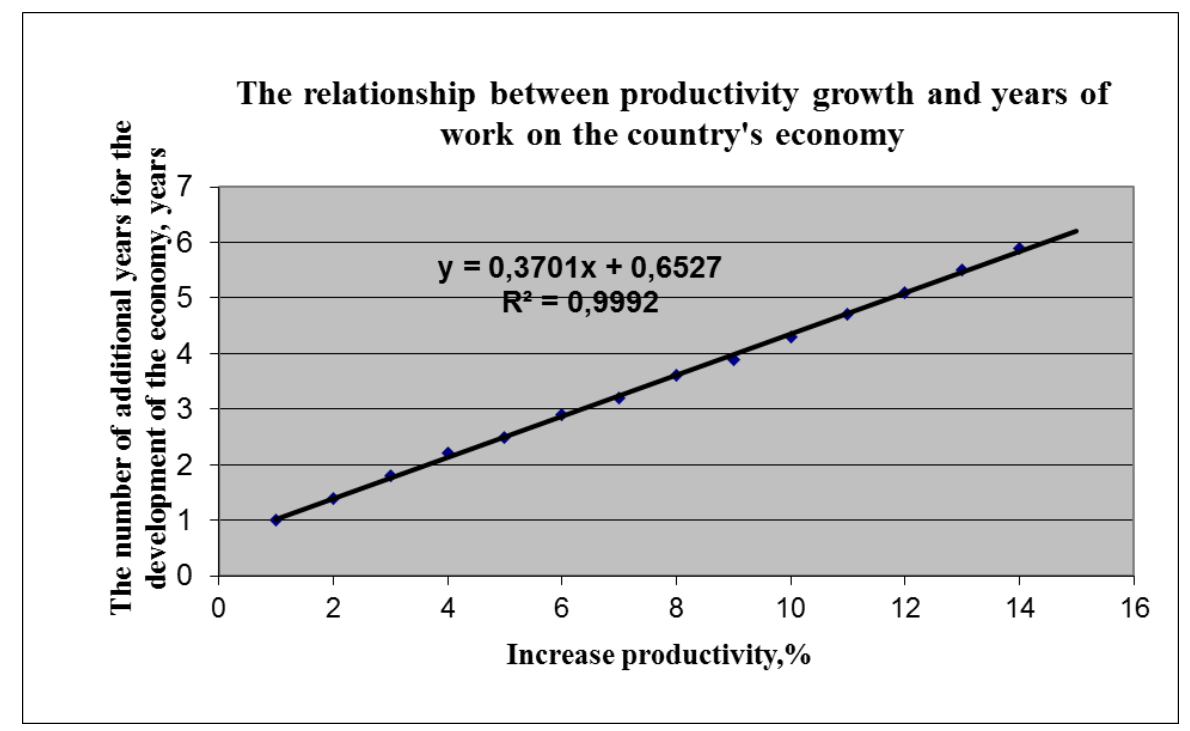

Fig. 3. - Dependence of the increase in years on the development of the economy with a planned increase in labor productivity.

Certainly, the issues related to raising the labor productivity are a litmus test of the government's capacity. The state should make a choice: decrease the number of employees or 
create new jobs; increase the unemployment or increase the social benefits; new markets or exclusion of competitors with higher production costs and etc.

Let us express the value of labor costs (working life) through some economic indicators of the country's life (see Table 2).

Table 2 - Interaction model of business and state in relation to labor.

\begin{tabular}{|c|c|c|c|}
\hline & & \multicolumn{2}{|c|}{ Values } \\
\hline & & $\begin{array}{c}\text { Government } \\
\text { costs }\end{array}$ & Labor costs \\
\hline 1 & Budget costs for the work of the Federal Assembly in 2015 & $\begin{array}{c}5,34 \\
\text { billion rubles }\end{array}$ & 8421 \\
\hline 2 & Spending on the maintenance of the State Duma in 2015 & $\begin{array}{c}10 \\
\text { billion rubles }\end{array}$ & 15774 \\
\hline 3 & Income of 11 the rich governors of Russia in 2015 & $\begin{array}{c}\text { 3,2 } \\
\text { billion rubles }\end{array}$ & 5047 \\
\hline 4 & Income of 200 the rich businessmen of Russia in 2015 & 360 billion USD & 34063799 \\
\hline 5 & The outflow of capital abroad in 2016 & $\begin{array}{c}274,4 \\
\text { billion rubles }\end{array}$ & 432736 \\
\hline 7. & The external debt of the Russian Federation on 1 January 2016 & $\begin{array}{c}\text { 515,254 } \\
\text { billion USD }\end{array}$ & 56067320 \\
\hline
\end{tabular}

Source: Authors' calculations based on data from Federal State Statistics Service of Russian Federation ${ }^{2}$, Ministry of Finance of the Russian Federation ${ }^{3}$, The Guardian Journal ${ }^{4}$, Forbes Magazine ${ }^{5}$.

\section{Conclusions}

Based on the obtained results, we can declare that the executive and legislative branches of government, incl. government and business bear full professional and civic responsibility for using the fund of working time in the economy and for the labor productivity of each worker. In conclusion, the following should be noted:

1) there is a clear flow of money to the private sector (we can even say that this happens with the government's calm attitude);

2) these money transfers to the private sector are financed by the public sector and the electorate;

3) the government will compensate for the shortage of money in the budget by selling state assets to the business and further reducing the living standards of the population;

4) the modern methodology of scientific research and the possibilities of computational methods make it possible to build an economic model of the state of any complexity and to 
make well-founded governing decisions both in eliminating deformations and in developing the country;

5) the liberal market relations have created the "deforming pressures" in the Russian economy in the form of a private economy that seeks to live "by itself" and "better than others and at the expense of others";

6 ) it is necessary to create its own unique mechanism for connecting the planned and market economy within the new socio-economic formation;

7) a multi-vector normative matrix for the planning of the balance of labor costs, labor losses, and the distribution of labor across all areas of the country's development should be developed.

\section{References}

1. V.S.Osipov, T.V. Skryl, The Strategic Directions of the Modern Russian Economic Development. International Business Management. 2016. T. 10. \# 6. P. 710-717.

2. Federal State Statistics Service of Russian Federation. URL: http://www.gks.ru/wps/wcm/connect/rosstat_main/rosstat/en/main/ (02.8.2017)

3. Ministry of Finance of the Russian Federation. URL: $\quad$ http://www.gubernia.com/news/economy/uvelichit-raskhody-na-soderzhaniegosdumy-i-soveta-federatsii-predlagaet-minfin/ (03.8.2017)

4. The Guardian Journal.

URL: https://www.theguardian.com/business/2016/may/08/offshore-financeemerging-countries-russia-david-cameron-summit (03.8.2017)

5. F. Magazine, URL: http://www.forbes.ru/rating-photogallery/290785-samye-bogatyegubernatory-rossii-2015/photo/1 (03.8.2017) 